\title{
Overexpression of the HspL Promotes Agrobacterium tumefaciens Virulence in Arabidopsis Under Heat Shock Conditions
}

\author{
Hau-Hsuan Hwang, Yin-Tzu Liu, Si-Chi Huang, Chin-Yi Tung, Fan-Chen Huang, \\ Yun-Long Tsai, Tun-Fang Cheng, and Erh-Min Lai
}

First author: Department of Life Sciences and Ph.D. Program in Microbial Genomics, National Chung Hsing University, Taichung, 402, Taiwan; second, third, fourth, fifth, and seventh authors: Department of Life Sciences, National Chung Hsing University; fifth author: Ph.D. Program in Microbial Genomics, National Chung Hsing University and Academia Sinica, Taichung, Taiwan, 402; and sixth and eighth authors: Institute of Plant and Microbial Biology, Academia Sinica, Taipei, 115, Taiwan. Accepted for publication 15 August 2014.

\begin{abstract}
Hwang, H.-H., Liu, Y.-T., Huang, S.-C., Tung, C.-Y., Huang, F.-C., Tsai, Y.-L., Cheng, T.-F., and Lai, E.-M. 2015. Overexpression of the HspL promotes Agrobacterium tumefaciens virulence in Arabidopsis under heat shock conditions. Phytopathology 105:160-168.

Agrobacterium tumefaciens transfers a specific DNA fragment from the resident tumor-inducing (Ti) plasmid and effector virulence (Vir) proteins to plant cells during infection. A. tumefaciens VirB1-11 and VirD4 proteins assemble as the type IV secretion system (T4SS), which mediates transfer of the T-DNA and effector Vir protein into plant cells, thus resulting in crown gall disease in plants. Previous studies revealed that an $\alpha$-crystallin-type, small heat-shock protein (HspL) is a more effective VirB8 chaperone than three other small heat-shock proteins (HspC,

HspAT1, and HspAT2). Additionally, HspL contributes to efficient T4SSmediated DNA transfer and tumorigenesis under room-temperature growth. In this study, we aimed to characterize the impact of HspL on Agrobacterium-mediated transformation efficiency under heat-shock treatment. During heat shock, transient transformation efficiency and VirB8 protein accumulation were lower in the $h s p L$ deletion mutant than in the wild type. Overexpression of $\mathrm{HspL}$ in A. tumefaciens enhanced the transient transformation efficiency in root explants of both susceptible and recalcitrant Arabidopsis ecotypes. In addition, the reduced transient transformation efficiency during heat stress was recovered by overexpression of $\mathrm{HspL}$ in A. tumefaciens. HspL may help maintain VirB8 homeostasis and elevate Agrobacterium-mediated transformation efficiency under both heat-shock and nonheat-shock growth.
\end{abstract}

Infection of susceptible plants by the phytopathogenic bacterium Agrobacterium tumefaciens results in crown gall tumors. The disease mechanism involves transfer of a specific DNA molecule (T-DNA) that has been processed from a large bacterial tumor-inducing (Ti) plasmid as well as effector virulence (Vir) proteins to plant cells. A. tumefaciens has a VirA/VirG two-component regulatory system that senses important environmental signals, including acidity, monosaccharides, and phenolic compounds, one of the most potent being acetosyringone (AS), to regulate vir gene induction $(8,17,31,43)$. The expression of VirD1 and VirD2 proteins leads to the production of single-stranded T-DNA which, when capped at the $5^{\prime}$ end with the VirD2 protein, is transported into plant cells. After entering plant cells, proper coordination of several Vir and plant protein functions ensures successful transport, integration, and expression of the T-DNA into the plant genome $(17,31,43)$.

Effector Vir proteins and T-DNA translocation across the bacterial cell envelope is mediated by a type IV secretion system (T4SS) composed of the VirB1-11 proteins, as well as VirD4, a member of a large family of membrane proteins implicated in the coupling of DNA transfer intermediates to the secretion machinery $(9,64)$. The T4SS contains two functional components: a filamentous T-pilus and a membrane-associated transporter complex. Results from genetic, biochemical, and protein-protein

Corresponding author: H.-H. Hwang;

E-mail address: hauhsuan@dragon.nchu.edu.tw

* The $e$-Xtra logo stands for "electronic extra" and indicates that the online version contains one supplemental figure.

http://dx.doi.org/10.1094/PHYTO-05-14-0133-R

(C) 2015 The American Phytopathological Society interaction studies have revealed that VirB4 and VirB6 to VirB10 are important for T-pilus and secretion channel assembly and function. The three inner-membrane proteins (VirB3, VirB6, and VirB8), along with the ATPases (VirB4, VirB11, and VirD4), form the cytoplasmic membrane translocon $(9,60)$. VirB2 protein is processed and subsequently cycled to form the T-pili filament $(13,32)$. The minor component of the T-pilus, VirB5, is located at the T-pilus tip and may directly contact host proteins during $A$. tumefaciens infection (2). From results obtained from transfer DNA immuonprecipitation (TrIP) assays, the T-DNA substrate contacts 6 of the 12 subunits of the T4SS machine, including the VirD4 receptor, followed by VirB11 ATPase, VirB6/VirB8, and VirB2 pilin/VirB9 proteins, which further supports the idea that the transfer mechanism has many features in common with conjugal DNA transfer between bacteria $(9,10,64)$.

Early studies revealed that $A$. tumefaciens virulence was strongly reduced at temperatures above $29^{\circ} \mathrm{C}$, which agrees well with significant reduction of the assembly and stability of the TDNA transfer complex composed of 11 VirB and VirD4 proteins at elevated temperatures $(6,15,33)$. The A. tumefaciens strain C58 has four $\alpha$-crystallin-type small heat shock protein ( $s h s p)$ genes: one on the circular chromosome $(h s p C)$, one on the linear chromosome ( $h s p L)$, and two on the pAtC58 plasmid ( $h s p A T 1$ and $h s p A T 2)$ (4). The expression of the linear chromosome- and pAtC58 plasmid-encoded $s h s p$ genes is induced by heat shock. The heatinduced expression of $h s p L$ is regulated by $\mathrm{RpoH}$, an alternative $\sigma^{32}$-like transcription factor, whereas that of $h s p A T 1$ and $h s p A T 2$ is regulated by the repression of the heat shock gene expression element (ROSE) in their $5^{\prime}$ untranslated region (4).

The sHsps are low-molecular-mass chaperones that can stably bind to unfolded proteins and prevent them from heat-induced aggregation (42). The sHsp functions as an ATP-independent mo- 
lecular chaperone and requires the formation of a dynamic quaternary structure by assembling into oligomeric complexes for its activity $(7,16)$. In addition to being induced by heat stress, the expression of $h s p L$ but not $h s p C$, $h s p A T 1$, and $h s p A T 2$ is induced by the vir gene inducer AS at room temperature (59). The HspL protein is mainly localized in the inner membrane and directly interacts with VirB8 in A. tumefaciens (57). Thermal aggregation protection assays demonstrated that the VirB8 chaperone activity of $\mathrm{HspL}$ is relatively more efficient than that of the other three sHsps $(57,58)$. The absence of HspL affects the tumorigenesis and VirB/D4-mediated conjugal DNA transfer efficiency, which demonstrates the important roles of the sHsp in T4SS stability and A. tumefaciens virulence with room-temperature growth (59).

In this study, we further established the important role of $\mathrm{HspL}$ in A. tumefaciens virulence under heat shock conditions. VirB8 protein accumulation and Agrobacterium transformation efficiency were lower under heat stress than at room temperature. Importantly, heat-reduced VirB8 protein level and transformation efficiency was accelerated in the $h s p L$ mutant. Overexpression of $\mathrm{HspL}$ in A. tumefaciens enhanced the transient transformation efficiencies of both susceptible and recalcitrant Arabidopsis ecotypes. This study further reveals a critical role of HspL in maintaining VirB8 homeostasis and in promoting A. tumefaciens transient transformation efficiency during heat stress.

\section{MATERIALS AND METHODS}

Plasmid constructions. We first generated the HspL overexpression cassette. A. tumefaciens cells grown overnight in 523 medium (24) with appropriate antibiotics were used to isolate genomic DNA with the Qiagen genomic DNA kit (Qiagen, Valencia, CA). The polymerase chain reaction (PCR) product was amplified with use of the Advantage 2 PCR Enzyme System (BD Biosciences Clontech, Palo Alto, CA) with $1 \mu \mathrm{g}$ of genomic DNA as the template. The PCR amplification cycles were as follows: $95^{\circ} \mathrm{C}$ for $2 \mathrm{~min}(1 \mathrm{cycle}) ; 95^{\circ} \mathrm{C}$ for $1 \mathrm{~min}, 56^{\circ} \mathrm{C}$ for $1 \mathrm{~min}$, and $72^{\circ} \mathrm{C}$ for $1 \mathrm{~min} /$ per kb ( 35 cycles); and $72^{\circ} \mathrm{C}$ for $10 \mathrm{~min}$ ( 1 cycle). The $h s p L$ gene was amplified from $A$. tumefaciens genomic DNA with the primer sequences for HspL-rbs-KpnI-F (5'-GTGGT ACCATCGCCAGAATGGGATG-3') and HspL-R-stop (5'-GAA AGCTTACTATTAGTTGACCTGA-3') (with primer sequences of designed restriction enzyme sites shown in bold and comple- mentary to the specific region in the A. tumefaciens genome in italics) and cloned into the pTrc200 vector (48), which resulted in the plasmid pTrc-hspLstop.

The HspL overexpression cassette was digested with $P v u \mathrm{I} /$ HindIII from the plasmid pTrc-hspLstop, and both ends of the DNA fragment were filled with DNA polymerase I (New England Biolabs Inc., Ipswich, MA) to create blunt ends. The plasmid pCAMBIA1305.02 was digested with SacII and filled with DNA polymerase I and ligated with the HspL overexpression cassette to create the plasmid pCAMBIA1305.02-HspL. Other plasmids used in this study are in Table 1.

Bacterial strains and culture. A. tumefaciens and Escherichia coli strains used in this study are in Table 1. A. tumefaciens strains were grown in 523 medium or on 523 agar supplemented with appropriate antibiotics (erythromycin at $50 \mu \mathrm{g} \mathrm{ml}^{-1}$, rifampicin at $50 \mu \mathrm{g} \mathrm{ml}^{-1}$, gentamycin at $50 \mu \mathrm{g} \mathrm{ml}^{-1}$, spectinomycin at $100 \mu \mathrm{g}$ $\mathrm{ml}^{-1}$, and kanamycin at $20 \mu \mathrm{g} \mathrm{ml}^{-1}$ ) (MDBio Inc., Taipei, Taiwan) at $28^{\circ} \mathrm{C}$. E. coli strains were grown at $37^{\circ} \mathrm{C}$ in $2 \times \mathrm{YT}$ medium (46) containing appropriate antibiotics (kanamycin at $50 \mu \mathrm{g} \mathrm{ml}^{-1}$ ).

Immunoblot analysis. To induce the overexpression of sHsps from pTrc200 (58) in A. tumefaciens, bacteria were first grown overnight in 523 medium with appropriate antibiotics and subcultured in acidic AB-MES medium (33) without antibiotics at an absorbance at $600 \mathrm{~nm}\left(\mathrm{~A}_{600}\right)=0.1$. After growth at $28^{\circ} \mathrm{C}$ to mid$\log$ phase for $6 \mathrm{~h}$, bacterial cultures were further cultivated for $24 \mathrm{~h}$ at $28^{\circ} \mathrm{C}$ containing $200 \mu \mathrm{M}$ AS (Sigma-Aldrich, St. Louis) with or without $0.4 \mathrm{mM}$ isopropyl- $\beta$-D-thiogalactopyranoside (IPTG) (MDBio Inc.), followed by heat-shock treatments at $37^{\circ} \mathrm{C}$ for 2 or $6 \mathrm{~h}$ or at $42^{\circ} \mathrm{C}$ for $1 \mathrm{~h}$. To determine the VirB8 protein level in A. tumefaciens, bacteria were cultured in acidic AB-MES medium without antibiotics to $\mathrm{A}_{600}=0.4$, cultured for $16 \mathrm{~h}$ at $28^{\circ} \mathrm{C}$ with $200 \mu \mathrm{M}$ AS, then transferred to $37^{\circ} \mathrm{C}$ for 15,30 , or $45 \mathrm{~min}$.

Bacterial cultures were collected at different times and protein was isolated as described (22). In brief, bacterial cells were harvested by centrifugation at $10,000 \times \mathrm{g}, 4^{\circ} \mathrm{C}$, for $10 \mathrm{~min}$ and resuspended in Tris-EDTA buffer $(10 \mathrm{mM}$ Tris- $\mathrm{HCl}$ and $1 \mathrm{mM}$ EDTA) to $\mathrm{A}_{600}=10$, then boiled for $10 \mathrm{~min}$ with $4 \times$ sample loading buffer $(0.25 \mathrm{M}$ Tris- $\mathrm{HCl}, 9 \%$ sodium dodecyl sulfate [SDS], and $30 \%$ glycerol) to disrupt cells. Protein concentration was measured by a BCA protein assay (Pierce Biotechnology, Rockford, IL) with a Power Wave X 340 Microplate Reader (BioTek Instruments, Winooski, VT). In total, $15 \mu \mathrm{g}$ of crude protein

TABLE 1. Bacterial strains and plasmids

\begin{tabular}{|c|c|c|}
\hline Strains, plasmids & Relevant characteristics ${ }^{\mathrm{a}}$ & Reference, source \\
\hline \multicolumn{3}{|l|}{ Strains } \\
\hline \multicolumn{3}{|l|}{ Agrobacterium tumefaciens } \\
\hline NT1RE(pJK270) & $\begin{array}{l}\mathrm{Rm}^{\mathrm{R}} \mathrm{Em}^{\mathrm{R}}, \mathrm{Km}^{\mathrm{R}} / \mathrm{Nm}^{\mathrm{R}}, \mathrm{pJK} 270 \text { is } \mathrm{pTiC}^{2} 8 \operatorname{Tra}^{\mathrm{C}} \text { with } \operatorname{Tn} 5 \text { insertion in T-DNA region without } \\
\text { affecting virulence }\end{array}$ & 26 \\
\hline $\operatorname{EML1057}(\Delta h s p L)$ & $\mathrm{Rm}^{\mathrm{R}} \mathrm{Em}^{\mathrm{R}}, \mathrm{Km}^{\mathrm{R}} / \mathrm{Nm}^{\mathrm{R}}$, markerless $h s p L$ deletion mutant in NT1RE(pJK270) & 59 \\
\hline EML1280( $(\Delta h s p L+h s p L)$ & $\mathrm{Rm}^{\mathrm{R}} \mathrm{Em}^{\mathrm{R}}, \mathrm{Km}^{\mathrm{R}} / \mathrm{Nm}^{\mathrm{R}}, \mathrm{Tc}^{\mathrm{R}}, \mathrm{pHspL}$ in $\Delta h s p L$ for complementation experiment & 59 \\
\hline GV3101(pMP90) & $\mathrm{Rm}^{\mathrm{R}} \mathrm{Gm}^{\mathrm{R}}, \mathrm{GV} 3101$ harboring pTiC58 $\Delta \mathrm{T}$-DNA & 29 \\
\hline \multicolumn{3}{|l|}{ Escherichia coli } \\
\hline \multicolumn{3}{|l|}{ Plasmids } \\
\hline pTrc200 & $\mathrm{Sp}^{\mathrm{R}}, \mathrm{pVS} 1$ origin lacIq, trc promoter expression vector & 48 \\
\hline pTrc-hspLstop & $\mathrm{Sp}^{\mathrm{R}}$, the $H s p L$ gene fragment in $\mathrm{p} \operatorname{Trc} 200$ vector & This study \\
\hline pTrcHspL-His & $\mathrm{Sp}^{\mathrm{R}}$, expression of HspL-His by trc promoter in $\mathrm{pTrc} 200$ vector & 58 \\
\hline pTrcHspC-His & $\mathrm{Sp}^{\mathrm{R}}$, expression of HspC-His by trc promoter in pTrc200 vector & 58 \\
\hline pTrcHspAT1-His & $\mathrm{Sp}^{\mathrm{R}}$, expression of HspAT1-His by trc promoter in pTrc200 vector & 58 \\
\hline pTrcHspAT2-His & $\mathrm{Sp}^{\mathrm{R}}$, expression of HspAT2-His by trc promoter in $\mathrm{pTrc} 200$ vector & 58 \\
\hline
\end{tabular}

${ }^{a} \mathrm{Cm}^{\mathrm{R}}, \mathrm{Em}^{\mathrm{R}}, \mathrm{Gm}^{\mathrm{R}}, \mathrm{Km}^{\mathrm{R}}, \mathrm{Nm}^{\mathrm{R}}, \mathrm{Rm}^{\mathrm{R}}, \mathrm{Sp}^{\mathrm{R}}$, and $\mathrm{Tc}^{\mathrm{R}}$ indicate resistant to chloramphenicol, gentamicin, erythromycin, kanamycin, neomycin, rifampicin, spectinomycin, and tetracycline, respectively. 
extract was equally loaded and resolved on $16.5 \%$ Tricine SDSpolyacrylamide gels (MDBio Inc.), then transferred to Hybond ECL Nitrocellulose membrane (Amersham Biosciences, Uppsala, Sweden), which was incubated with primary antibodies for HspL $(1: 20,000)$ (59), VirB8 (1:10,000) (6), VirB2 $(1: 1,000)(49)$, RNA polymerase $\alpha$ subunit (RpoA antibody) $(1: 7,500)(36,58)$, or neomycin phosphotransferase II (NptII) $(1: 50,000)$ (Sigma-Aldrich), then with horseradish peroxidase-conjugated goat anti-rabbit immunoglobulin G antibody (1:50,000) (Chemicon International, Inc., Temecula, CA). The membranes were developed by chemiluminescent detection (PerkinElmer Life and Analytical Sciences, Boston) and underwent autoradiography.

Transient transformation assay of Arabidopsis. Transient transformation assay of Arabidopsis roots was as described (21, 22), with minor modifications. The 523 medium-grown bacterial cells were washed with $0.9 \%$ sodium chloride and resuspended in $0.9 \%$ sodium chloride at $10^{7}$ or $10^{8}$ colony forming units (CFU) $\mathrm{ml}^{-1}$. Root segments of more than 10 different 3- to 4-week-old Arabidopsis thaliana plants were infected with A. tumefaciens strains containing the binary vectors pCAMBIA2201-Gm, pCAMBIA1201Gm (22), pCAMBIA1305.02-HspL, or pCAMBIA1305.02 (18, 19). Prepared roots and bacteria were co-cultivated on Murashige and Skoog (MS) medium at $28^{\circ} \mathrm{C}$ for 2 days.

For transient transformation assay of $A$. tumefaciens strains containing the pTrc200 vectors, bacterial cells first grown in 523 medium overnight were cultivated for $24 \mathrm{~h}$ at $28^{\circ} \mathrm{C}$ in acidic ABMES medium with $200 \mu \mathrm{M}$ AS and $0.4 \mathrm{mM}$ IPTG to induce vir and $s H$ sps expression, respectively. After AS and IPTG induction, bacterial cells were washed and resuspended in $0.9 \%$ sodium chloride at $10^{7}$ or $10^{8} \mathrm{CFU} \mathrm{ml^{-1 }}$ for transformation assays. For heat treatments in transient transformation assays, roots and bacteria were first incubated at $37^{\circ} \mathrm{C}$ for $0.5,2$, or $6 \mathrm{~h}$ or at $42^{\circ} \mathrm{C}$ for $1 \mathrm{~h}$ on MS medium, then incubated at $28^{\circ} \mathrm{C}$ for 2 days.

At least 70 root segments from each plant were examined during each independent transformation assay. At 6 or 7 days after A. tumefaciens infection, Arabidopsis root segments were stained with 5-bromo-4-chloro-3-indolyl $\beta$-D-glucuronic acid staining solution (22) for 1 day at $37^{\circ} \mathrm{C}$. Root segments were observed under a stereoscopic microscope to determine transient transformation efficiency. Data represent mean transformation frequency from at least three independent experiments.

Arabidopsis root attachment assays. Arabidopsis root attachment assays were as described (56), with minor modification. Roots of 14-day-old Arabidopsis thaliana seedlings grown on B5 agar medium were cut into $1-\mathrm{cm}$ segments and transferred to sterile dishes with $1 \mathrm{mM} \mathrm{CaCl}_{2}$ and $0.4 \%$ sucrose solutions. Agrobacterium tumefaciens strains were first transformed with a green fluorescent protein (GFP) reporter plasmid, pJZ383 (56), by electroporation. Then, bacteria at $10^{7} \mathrm{CFU} \mathrm{ml} \mathrm{m}^{-1}$ were co-incubated with more than five root segments at $19^{\circ} \mathrm{C}$ in the dark for $48 \mathrm{~h}$ with shaking at very low speed $(50 \mathrm{rpm})$. After co-incubation for $8 \mathrm{~h}$, root segments were recovered, rinsed, resuspended in fresh $\mathrm{CaCl}_{2}$ and sucrose solutions, placed on slides, and observed under an Olympus IX71 fluorescence microscope (Olympus Optical Co., Tokyo) with the DP Controller program.

\section{RESULTS}

The A. tumefaciens hspL mutant showed reduced transient transformation efficiency in Arabidopsis under heat shock. Previous studies have demonstrated that the HspL protein directly interacts with the VirB8 protein and protects the GST-VirB8 fusion protein against thermal aggregation in vitro (57). The levels of several AS-induced VirB proteins were reduced in the $A$. tumefaciens $h s p L$ deletion mutant grown at room temperature (59). To investigate whether the HspL level was associated with VirB8 level in A. tumefaciens under heat stress, we determined the VirB8 level in the wild type and $h s p L$ deletion mutant during different times of $37^{\circ} \mathrm{C}$ heat-shock treatment. The AS-induced VirB8 protein level was decreased in both the wild type and $h s p L$ deletion mutant with increasing heat-shock treatment from 0 to 45 min (Fig. 1A). In addition, reduction in AS-induced VirB8 level was greater in the $h s p L$ deletion mutant than the wild type (Fig. 1A and 1). After the 15-min heat-shock treatment, the ASinduced VirB8 protein level was reduced to $24 \%$ of the original protein level in the $h s p L$ mutant but $42 \%$ in the wild type (Fig. 1B). After the 45-min heat shock, the AS-induced VirB8 protein level was reduced to $7 \%$ in the $h s p L$ deletion mutant but $25 \%$ in the wild type (Fig. 1B). In contrast, AS-induced VirB2 protein level was not significantly altered by heat shock (Fig. 1A), which agrees with previous studies (6). These data suggest that the HspL protein may be required to maintain VirB8 protein homeostasis in A. tumefaciens under heat stress.

Because of the reduced VirB8 protein level in A. tumefaciens with heat shock, we next examined the transient transformation efficiency of A. tumefaciens in Arabidopsis roots with and without a 30-min heat shock. Root segments of Arabidopsis plants were infected with the A. tumefaciens strains containing the binary vector pCAMBIA1201-Gm on MS medium at $28^{\circ} \mathrm{C}$ for 2 days. For heat-shock treatments, roots and bacteria were first incubated at $37^{\circ} \mathrm{C}$ for $30 \mathrm{~min}$ on $\mathrm{MS}$ medium, then at $28^{\circ} \mathrm{C}$ for 2 days. The transient transformation efficiency of the $h s p L$ deletion mutant was less than $50 \%$ of the wild-type efficiency (Fig. $1 \mathrm{C})$, whereas the $h s p L$-complemented strain restored the reduced transient transformation efficiency of the $h s p L$ mutant to the wildtype efficiency (Fig. 1C). After heat-shock treatment, the wild type and $h s p L$-complemented strain both showed more than onethird reduction in transient transformation efficiency as compared with no heat-shock treatment (Fig. 1C). In the $h s p L$ mutant, transient transformation efficiency was lower, by approximately $45 \%$, with than without heat-shock treatment. In addition, bacterial growth rates did not differ between the $h s p L$ deletion mutant, the wild type, and the $h s p L$-complemented strains when grown in acidic minimal medium at $28^{\circ} \mathrm{C}$ for $24 \mathrm{~h}$ with $\mathrm{AS}$ induction, followed by $37^{\circ} \mathrm{C}$ heat-shock treatment for up to $6 \mathrm{~h}$ (Supplemental Figure 1). These data suggest that the HspL protein may play a role in enhancing Agrobacterium transformation efficiency under heat stress.

Overexpression of HspL but not HspC, HspAT1, or HspAT2 in the wild-type A. tumefaciens enhanced transient transformation efficiency in Arabidopsis. In A. tumefaciens, tumorigenesis and T4SS-mediated RSF1010 transfer efficiency was affected more by the deletion of four shsp genes (HspL, HspC, $H s p A T 1$, and HspAT2) than by single $h s p$ deletion (58). All four sHsps equally possess chaperone activities for the model substrate citrate synthase in vitro (58). However, among the four sHsps, only HspL functions as an efficient molecular chaperone in preventing GST-VirB8 proteins from thermal aggregation (58). We determined whether overexpression of each of the four sHsps in wild-type $A$. tumefaciens could enhance the VirB8 protein stability and, therefore, affect A. tumefaciens transient transformation efficiency. We successfully induced overexpression of the four His-tagged sHsps from the trc promoter in wild-type $A$. tumefaciens by adding IPTG to AB-MES media with AS at $28^{\circ} \mathrm{C}$ (58) (Fig. 2A). In the wild type, accumulation of His-tagged HspL, HspC, HspAT1, and HspAT2 was greater with than without IPTG (Fig. 2A). The levels of HspL, VirB8, and VirB2 proteins were increased because of the presence of the vir gene inducer AS (Fig. 2A). When co-expressed with either one of the four Histagged sHsps, VirB8 showed a slightly higher level with IPTG than empty-vector (pTrc200) induction. In contrast, VirB2 protein level did not differ with empty-vector or IPTG induction. The level of NptII protein as a loading control was similar in all tested strains with or without IPTG. Therefore, each of four sHsps overexpressed in the wild type may help to stabilize the VirB8 protein, which agrees with previous studies (58). 
We determined the transient transformation efficiency of these strains with and without IPTG treatment. Only the wild-type strain with the IPTG-induced His-tagged HspL protein showed significantly higher transient transformation efficiency than all the other four strains in the presence of IPTG (Fig. 2B). In the absence of IPTG, transient transformation efficiency of the wild type with each of the four sHsps did not differ from the wild type with empty vector (Fig. 2B). Overexpression of each of the four sHsps in the wild type may enhance VirB8 accumulation; however, only the wild type with IPTG-induced His-tagged HspL protein could efficiently increase $A$. tumefaciens virulence.

We next determined whether overexpression of $\mathrm{HspL}$ protein in the wild type could affect A. tumefaciens VirB8 protein level under heat stress. The addition of AS induced HspL, VirB8, and VirB2 protein expression with empty vector or His-tagged HspL grown at $28^{\circ} \mathrm{C}$ with and without IPTG. With a shift of bacteria to $37^{\circ} \mathrm{C}$ for $2 \mathrm{~h}$ or $42^{\circ} \mathrm{C}$ for $1 \mathrm{~h}$, HspL protein level was further increased with the empty vector with or without IPTG (Fig. 2C). Although the HspL level was induced by a short period of heatshock treatment, VirB8 protein stability was still affected by the heat stress. VirB8 level was lower in the wild type with the empty vector grown at $37^{\circ} \mathrm{C}$ for $2 \mathrm{~h}$ or $42^{\circ} \mathrm{C}$ for $1 \mathrm{~h}$ than at $28^{\circ} \mathrm{C}$ (Fig. $2 \mathrm{C})$. In contrast, both VirB2 and NptII protein levels were not significantly affected by the heat-shock treatments. HspL level was slightly decreased on transfer of the wild-type bacteria with empty vector from 28 to $37^{\circ} \mathrm{C}$ for $6 \mathrm{~h}$. VirB8 similarly accumulated at the lowest level in the same strain when grown at $37^{\circ} \mathrm{C}$ for $6 \mathrm{~h}$ (Fig. 2C). Thus, a longer period of heat treatment may affect both HspL and VirB8 protein stability. In the presence of IPTG, the level of His-tagged HspL protein was higher with HspL-His than with empty vector (Fig. 2C). The level of VirB8 protein was also higher in the wild type overexpressing the HspLHis protein than in the wild type containing the empty vector under three kinds of heat-shock treatments. These data further support the idea that overexpression of HspL protein may help maintain VirB8 homeostasis in A. tumefaciens during heat stress.

We next examined the effect of heat-shock treatments on transient transformation efficiency during Agrobacterium and Arabidopsis root co-incubation. Root segments of Arabidopsis plants were infected with the $A$. tumefaciens strains containing the pTrc200 vectors and the binary vector pCAMBIA2201-Gm on MS medium at $28^{\circ} \mathrm{C}$ for 2 days. For heat-shock treatments, roots and bacteria were first incubated at $37^{\circ} \mathrm{C}$ for 2 or $6 \mathrm{~h}$ or at $42^{\circ} \mathrm{C}$ for $1 \mathrm{~h}$ on $\mathrm{MS}$ medium, then at $28^{\circ} \mathrm{C}$ for 2 days. Transient transformation efficiency was reduced nearly one-third in the wild type with an empty vector after heat-shock treatment of $37^{\circ} \mathrm{C}$ for $2 \mathrm{~h}$ or $42^{\circ} \mathrm{C}$ for $1 \mathrm{~h}$ as compared with no heat-shock treatment (Fig. 2D). Transient transformation efficiency of the wild type
A

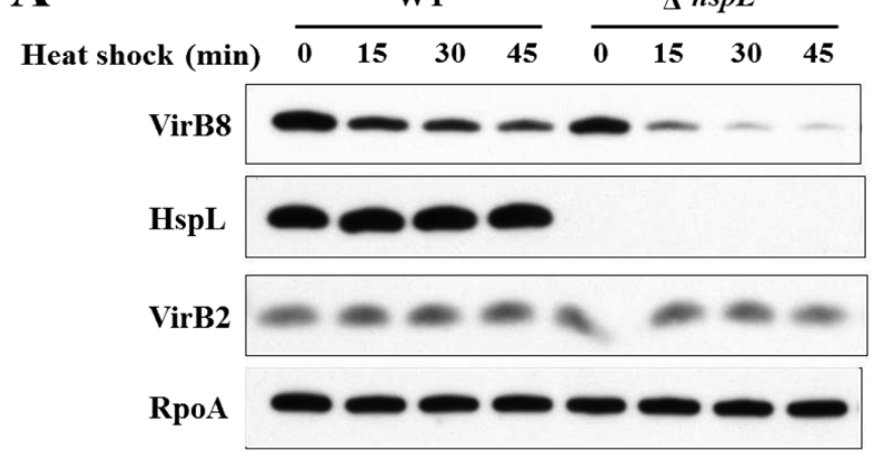

B

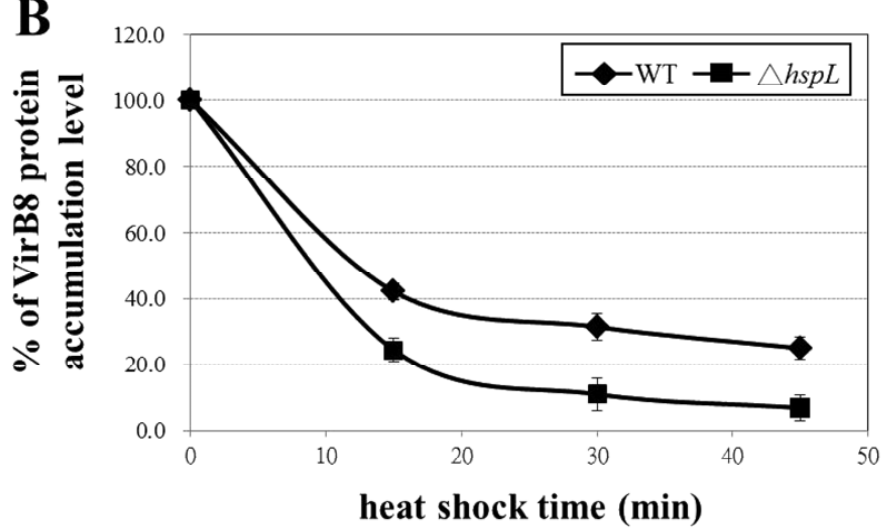

C

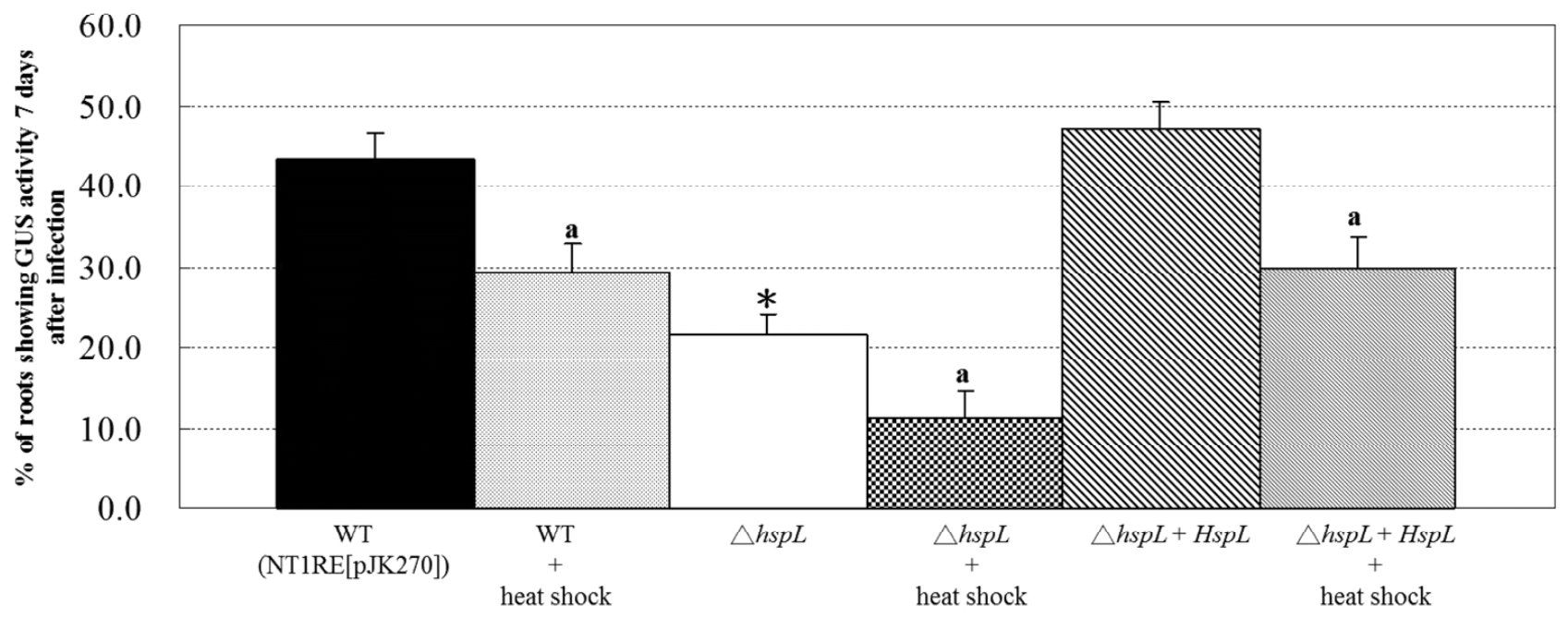

Fig. 1. The Agrobacterium tumefaciens hspL mutant showed reduced VirB8 protein level and transient transformation efficiency in Arabidopsis under heat shock. A, Immunoblot analyses of VirB8, HspL, VirB2, and RpoA in the wild type (WT) (NT1RE[pJK270]) and hspL deletion ( $\Delta$ hspL) A. tumefaciens strains grown in acidic AB-MES media with $200 \mu \mathrm{M}$ acetosyringone (AS) at $28^{\circ} \mathrm{C}$ for $16 \mathrm{~h}$, then $37^{\circ} \mathrm{C}$ for 15,30 , or $45 \mathrm{~min}$. RpoA was a loading control. B, Quantification of VirB8 protein level over time. The VirB8 protein accumulation of both strains were set to $100 \%$ under no-heat-shock treatment. The VirB8 accumulation at different times is relative to that at time 0 for each strain. C, Transient transformation efficiency of the WT, $h s p L$ mutant, and $h s p L$-complemented $(\Delta h s p L+H s p L)$ strains in Arabidopsis roots. Arabidopsis root segments were infected with bacteria of various A. tumefaciens strains at $10^{8} \mathrm{CFU} / \mathrm{ml}$ on Murashige and Skoog (MS) medium at $28^{\circ} \mathrm{C}$ for 2 days. For heat-shock treatments, roots and bacteria were first incubated at $37^{\circ} \mathrm{C}$ for 30 min on MS medium, then at $28^{\circ} \mathrm{C}$ for 2 days. Root segments were stained with 5-bromo-4-chloro-3-indolyl $\beta$-D-glucuronic acid staining solution 7 days after infection. Data are mean \pm standard error from at least three independent experiments. Symbols: * indicates $P<0.05$ compared with the WT by pairwise Student's $t$ test and "a" indicates significant difference $(P<$ 0.05 ) with and without heat treatment within the same strain during infection by pairwise Student's $t$ test. 
with the empty vector or His-tagged $\mathrm{HspL}$ was reduced most with heat-shock treatment of $37^{\circ} \mathrm{C}$ for $6 \mathrm{~h}$ than without heat-shock treatment (Fig. 2D). In the presence of IPTG, transient transformation efficiency was increased more than 1.5-fold with Histagged HspL overexpression than with the empty vector among the four tested experimental conditions (Fig. 2D). VirB8 level was positively associated with $A$. tumefaciens transient transformation efficiency (Fig. 2C and D). Thus, IPTG-induced His-tagged HspL expression greatly enhanced VirB8 protein stability and transient transformation efficiency of $A$. tumefaciens during heat stress.

Overexpression of $\mathrm{HspL}$ in A. tumefaciens increased transient transformation efficiency of several recalcitrant Arabidopsis ecotypes. We next examined whether overexpression of HspL in the wild type could increase A. tumefaciens transformation efficiency in other recalcitrant Arabidopsis ecotypes and mutants. We chose four Arabidopsis ecotypes (UE-1, Petergof, BL1, and Dijon-G) and two T-DNA insertion mutants, resistant to Agrobacterium transformation (rat3 and rat4) $(39,41$, $65)$, to determine the transient transformation efficiency of the hspL mutant and the HspL overexpression strain at room tem- perature. The ecotype UE-1 is likely blocked in T-DNA integration, thus resulting in higher transient transformation efficiency than other recalcitrant Arabidopsis ecotypes, including Petergof, BL1, and Dijon-G $(39,41)$. The A. tumefaciens infection processes of the ecotypes BL1 and Petergof and rat 3 and rat4 mutants are likely deficient in bacterial attachment, thus causing lower transient transformation efficiency than susceptible Arabidopsis ecotypes with $A$. tumefaciens infection $(39,41,65)$. On infection with wild-type $A$. tumefaciens, the transient transformation efficiency of Dijon-G was lowest among the four tested ecotypes and two tested rat mutants (Fig. 3A), which agrees with previous studies $(39,41)$. Similar to transient transformation results obtained with the ecotype Ws (Fig. 1C), the hspL mutant showed nearly one- to two-third reduction in transient transformation efficiency as compared with the wild type and $h s p L$-complemented strains on infection in the four Arabidopsis ecotypes and two rat mutants (Fig. 3A).

We inserted the HspL overexpression cassette into the pCAMBIA1305.02 binary vector and introduced the vector into the disarmed A. tumefaciens strain GV3101 for overexpressing

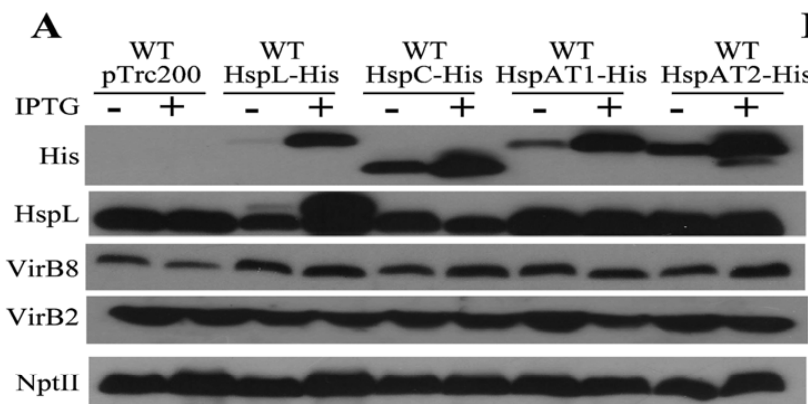

B

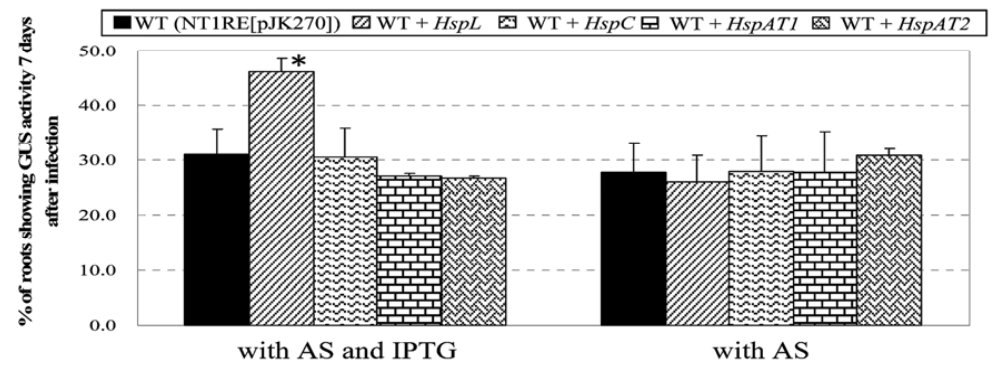

C

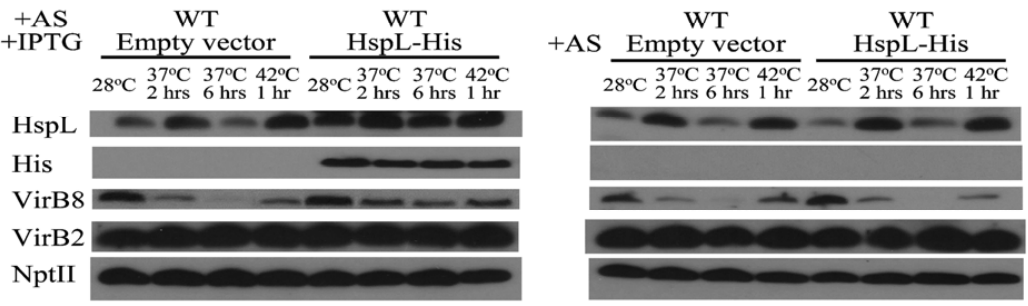

D

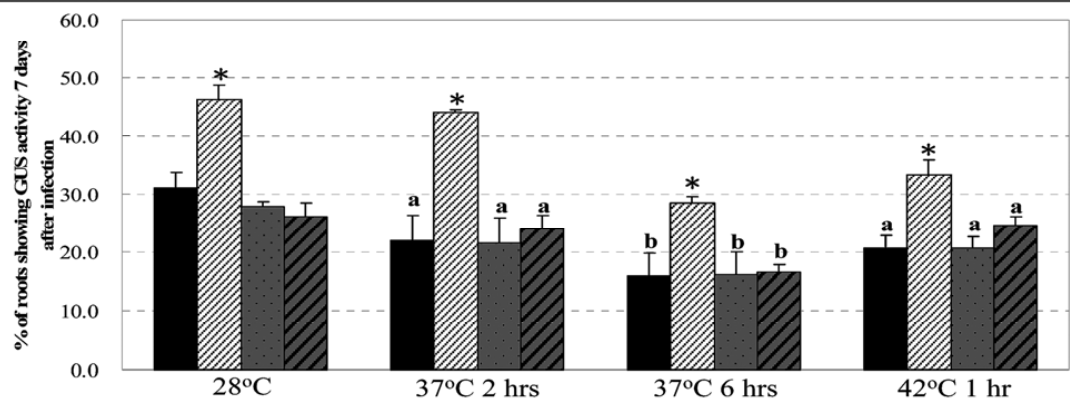

Fig. 2. Overexpression of the His-tagged HspL protein in wild-type (WT) Agrobacterium tumefaciens enhanced transient transformation efficiency in Arabidopsis under heat-shock treatment. A, Immunoblot analysis of the His-tagged sHsps HspL, VirB8, VirB2, and NptII in the WT (NT1RE[pJK270]) with the empty vector (pTrc200) or His-tagged sHsps grown in acidic AB-MES media with $200 \mu \mathrm{M}$ acetosyringone (AS) at $28^{\circ} \mathrm{C}$ for $16 \mathrm{~h}$ with and without isopropyl- $\beta$-Dthiogalactopyranoside (IPTG). NptII was a loading control. B, Transient transformation efficiency of the WT with the empty vector or overexpressing the IPTGinduced His-tagged HspL, HspC, HspAT1, or HspAT2 proteins in Arabidopsis roots. Arabidopsis root segments were infected with bacteria of various A. tumefaciens strains at $10^{7} \mathrm{CFU} / \mathrm{ml}$ on Murashige and Skoog (MS) medium containing $200 \mu \mathrm{M}$ AS with or without $0.4 \mathrm{mM}$ IPTG at $28^{\circ} \mathrm{C}$ for 2 days. Data are mean \pm standard error from at least three independent experiments. Symbol: * indicates $P<0.05$ between the WT with empty vector and IPTG-induced Histagged HspL protein by pairwise Student's $t$ test. C, Immunoblot analyses of level of HspL, His-tagged sHsps VirB8, VirB2, and NptII in the WT with the empty vector (pTrc200) or the His-tagged HspL protein grown in acidic AB-MES medium with $200 \mu \mathrm{M} \mathrm{AS}$ at $28^{\circ} \mathrm{C}$ for $16 \mathrm{~h}$, then $37^{\circ} \mathrm{C}$ for 2 or $6 \mathrm{~h}$ or $42^{\circ} \mathrm{C}$ for $1 \mathrm{~h}$ with and without IPTG. D, Transient transformation efficiency of the WT with the empty vector or overexpressing the IPTG-induced His-tagged HspL protein in Arabidopsis roots. Arabidopsis root segments were infected with bacteria of two A. tumefaciens strains at $10^{7} \mathrm{CFU} / \mathrm{ml}$ on MS medium containing $200 \mu \mathrm{M}$ AS with or without $0.4 \mathrm{mM}$ IPTG. During co-incubation, roots and bacteria were first incubated at $37^{\circ} \mathrm{C}$ for 2 or $6 \mathrm{~h}$, or at $42^{\circ} \mathrm{C}$ for $1 \mathrm{~h}$ on $\mathrm{MS}$ medium, then at $28^{\circ} \mathrm{C}$ for 2 days. Symbols: * indicates $P<0.05$ between the WT with empty vector and IPTG-induced His-tagged HspL under the same temperature by pairwise Student's $t$ test; "a" or "b" indicate significant difference $(P<0.05)$ with and without heat treatment with the same strain during infection by analysis of variance. 
HspL protein without IPTG induction. We detected HspL protein only in the HspL overexpression strain in the absence of AS (at $0 \mathrm{~h}$ ) (Fig. 3B). The level of HspL was relatively higher in the HspL overexpression strain than in the wild type GV3101 with the empty vector pCAMBIA1305.02 under AS induction. The ASinduced VirB8 protein accumulated at relatively higher levels at an early time of AS induction in the HspL overexpression strain, and its level was also positively associated with HspL level in the same strain. In contrast, the AS-induced VirD2 protein level was similar in both the wild type and the HspL overexpression strain.

We next performed transient transformation assays with these two strains under room-temperature growth on five tested Arabidopsis ecotypes (Ws, UE-1, Petergof, BL1, and Dijon-G) and the two rat mutants (rat3 and rat4). Similar to results shown in Figure $2 \mathrm{~B}$ and $\mathrm{D}$, constitutive overexpression of the HspL protein in the wild type enhanced the transient transformation efficiency 1.25- to 2-fold on infection with four of the Arabidopsis ecotypes (Ws, UE-1, Petergof, and BL1) and rat3 and rat4 but did not affect that of Dijon-G (Fig. 3C).

Overexpression of the $\mathrm{HspL}$ protein in the wild-type A. tumefaciens improved $A$. tumefaciens virulence on the attachmentdeficient Arabidopsis ecotypes Petergof and BL1 and attachmentdeficient rat mutants rat 3 and rat 4 . Therefore, we examined whether overexpression of the HspL protein in A. tumefaciens affected bacterial attachment on Arabidopsis roots. We used the wild-type and HspL overexpression strains with constitutively expressed GFP to determine bacterial aggregation on roots of the transformation-susceptible Arabidopsis ecotype Ws and transformation-recalcitrant Arabidopsis ecotype BL1. Previous studies showed that A. tumefaciens could not efficiently bind root seg- ments of the Arabidopsis ecotype BL1 (39,41,65). We observed less bacterial aggregation in roots of BL1 than Ws plants (Fig. 3D). However, the bacterial aggregation of both the wild type and the HspL overexpression strains on Ws or BL1 root segments were similar, which suggests that the overexpression of $\mathrm{HspL}$ protein in A. tumefaciens did not significantly enhance bacterial attachment ability on Arabidopsis roots.

\section{DISCUSSION}

Temperature is among the major physical factors affecting the growth and development of organisms on earth. Both prokaryotic and eukaryotic cells activate signaling pathways to adjust their metabolism and cell function to reduce heat-associated damage. Many phenotypic effects of heat stress are caused by the unspecific aggregation or incorrect folding of proteins and unbalanced protein homeostasis. In response to heat stress, cells cause the transient expression of a group of heat shock or heat stress proteins (Hsps). The Hsps function as molecular chaperones that bind to partially folded or denatured substrate proteins and prevent the formation of wrong protein aggregates or translocate nonfunctional proteins for degradation in lysosomes or proteasomes $(37,42,45)$. Among different members of Hsp families, the monomers of the sHsps are low, ranging from 15 to $30 \mathrm{kDa}$, and they have a highly conserved C-terminal $\alpha$-crystallin domain of 90 amino acids $(7,16,54)$. Depending on the organisms' ambient living environment, environmental temperature variations, and their genome size, the gene numbers encoding sHsps varies $(25,38,47,53)$. Different functions for multiple sHsps in different organelles and cell types under various stresses might have caused
A
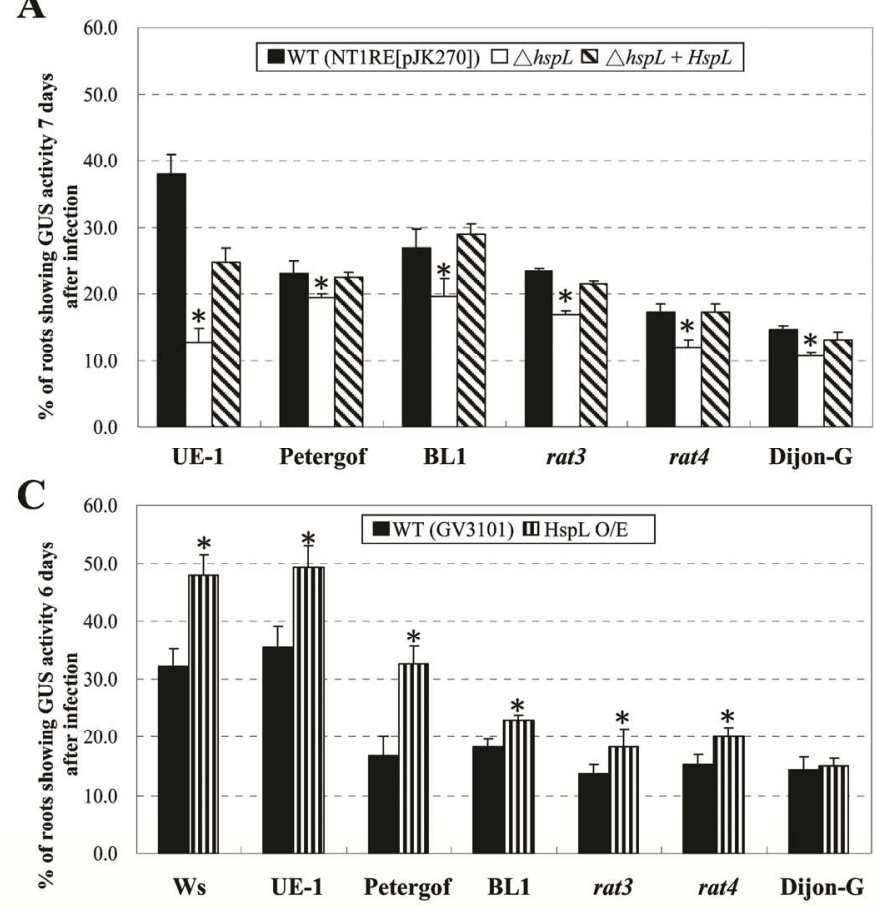

B

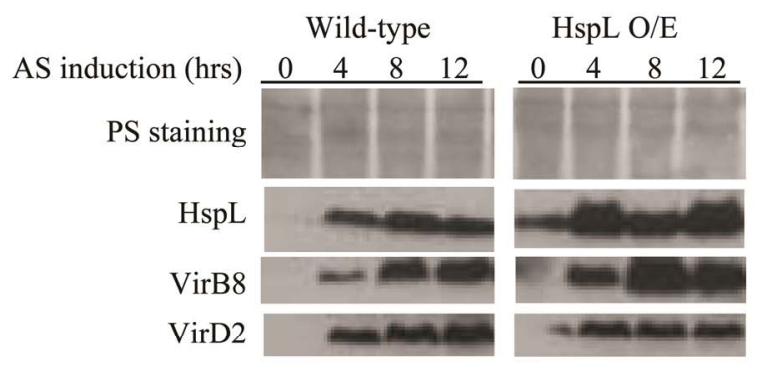

Ecotype Ws

D

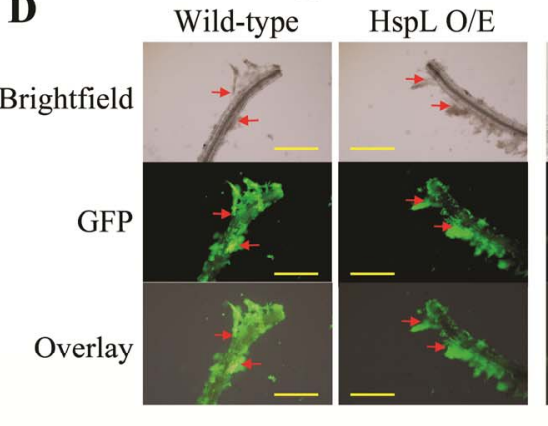

Ecotype BL1

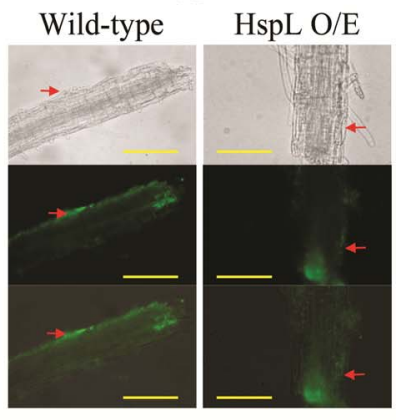

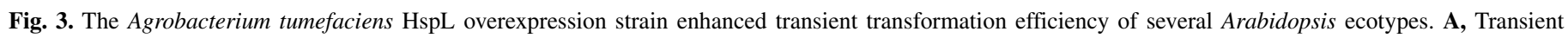

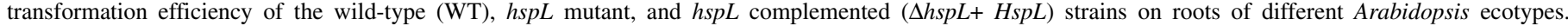

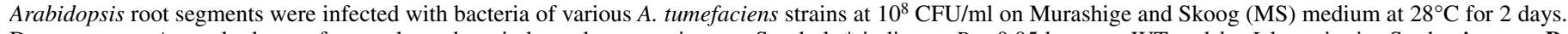

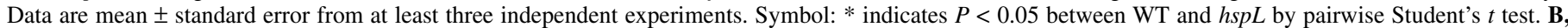

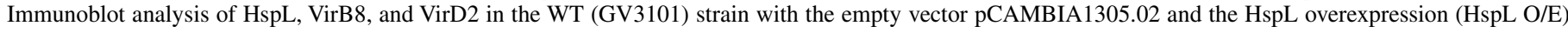

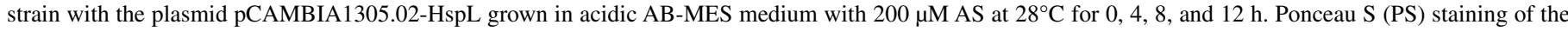

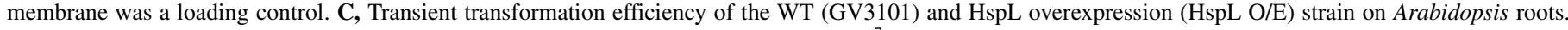

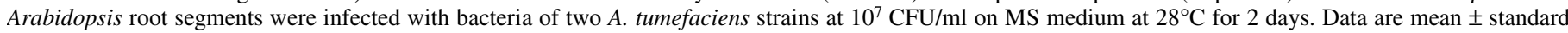

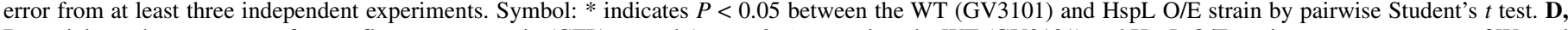

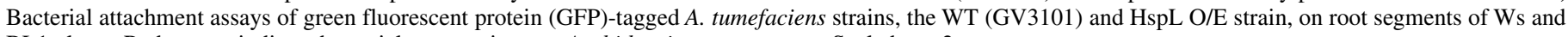
BL1 plants. Red arrows indicate bacterial aggregations on Arabidopsis root segments. Scale bars, $2 \mathrm{~mm}$. 
diversification $(34,42,53,55)$. Four $\alpha$-crystallin-type small heat shock genes- $h s p C, h s p L, h s p A T 1$, and $h s p A T 2$ - exist in different replicons of $A$. tumefaciens (4). All four sHsps exhibit similar chaperone activity for the model substrate citrate synthase but HspL possesses higher chaperone activity for the VirB8 protein (58). In this study, we successfully established that the absence of HspL protein in A. tumefaciens had adverse effects on VirB8 protein homeostasis and bacterial transient transformation efficiency under heat stress. This study corroborated further that the HspL protein functions as the most efficient chaperone for VirB8 and is important in transient transformation efficiency of $A$. tumefaciens under heat stress.

Transient transformation efficiency of the wild type decreased nearly one-third on co-incubation of bacteria and plant roots with a temperature increase from 28 to $37^{\circ} \mathrm{C}$ for up to $2 \mathrm{~h}$ or $42^{\circ} \mathrm{C}$ for $1 \mathrm{~h}$ (Figs. 1C and 2D). By increasing the co-incubation temperature from 28 to $37^{\circ} \mathrm{C}$ for $6 \mathrm{~h}$, the transient transformation efficiency was reduced nearly half that without heat treatment (Fig. 2D). Previous studies showed that the function and accumulation of several Vir proteins was significantly reduced at elevated temperatures $(6,15,23,33)$. The activation of vir genes is regulated by the VirA/VirG two-component regulatory system. With incubation temperature above $32^{\circ} \mathrm{C}$, VirA is inactive because of conformational change, which significantly affects downstream vir gene expression (23). Furthermore, the levels of several VirB proteins, VriD2, VirE2, as well as the T4SS assembly were substantially decreased with increased temperature $(6,15,33)$. We found that the level of VirB8 but not VirB2 was considerably reduced with increasing heat treatment time (Figs. 1A and 2C). Thus, stability of different VirB proteins in A. tumefaciens may differ at temperatures higher than room temperature, which agrees with previous study (6).

We found that, with lack of the VirB8 chaperone protein HspL, VirB8 protein level was significantly affected by heat-shock treatment, and heat-induced VirB8 degradation may furthermore decrease A. tumefaciens transient transformation efficiency as compared with the wild type under heat-shock treatment. In addition, IPTG-induced or constitutive overexpression of $\mathrm{HspL}$ protein in the wild type enhanced VirB8 protein abundance and $A$. tumefaciens virulence with heat-shock treatment time. Although the IPTG-induced overexpression of the other three sHspsHspC, HspAT1, and HspAT2-also increased VirB8 protein level in the wild type, only overexpression of HspL could increase $A$. tumefaciens transient transformation efficiency under heat-shock treatment. A previous study (58) also found no significant reduction in tumorigenesis efficiency in the $h s p C, h s p A T 1$, or $h s p A T 2$ single-deletion mutants, and HspL protein possessed higher VirB8 chaperone activity than HspAT2. Our data support the idea that HspL protein is the most efficient VirB8 chaperone (58), and it may play a major role in the A. tumefaciens-mediated transformation process under heat stress.

Previous studies revealed increased bacterial thermotolerance with overexpression of the recombinant rice OsHsp16.9-CI- $\beta$ glucuronidase (GUS) fusion protein or the chestnut CsHsp17.5 protein in E. coli $(52,62)$. Heat shock factor (HSF) is essential for the transcription of Hsps. Several gain-of-function studies demonstrated that overexpression of AtHSF1-GUS, AtHSF3, or AtHSF3$G U S$ in transgenic Arabidopsis derepressed the expression of several heat-shock genes at normal temperature and the level of basic thermotolerance was increased $(35,44,53)$. Data from our study and previous studies support the idea that overexpression of sHsps in both prokaryotic and eukaryotic organisms enhances heat stress tolerance.

We used various Arabidopsis ecotypes and mutants that are resistant to A. tumefaciens transformation to determine whether constitutive overexpression of HspL protein in the wild type could enhance $A$. tumefaciens virulence. The transient transformation efficiency was higher in the HspL overexpression strain than the wild type on infection of bacteria-attachment-deficient Arabidopsis mutants or ecotypes and the T-DNA-integration-deficient Arabidopsis ecotype. In addition, the bacterial aggregation of the HspL overexpression strain and the wild type did not differ; therefore, overexpression of the HspL protein may not directly affect bacteria attachment ability. Our data and those from previous studies $(57,58)$ demonstrate that overexpression of $\mathrm{HspL}$ in A. tumefaciens directly enhances VirB8 protein level. VirB8 protein is one of the core components of the T4SS machinery and may play a key role in maintaining the stability of the T4SS complex $(5,11,12,30,61)$. VirB8 also forms a dimer in A. tumefaciens; the dimer interface helps VirB2 protein target the T-pilus assembly sites and is required for proper T4SS functions $(9,51$, 63). Thus, VirB8 protein may function as a nucleating factor to help the T4SS machinery assembly $(1,9)$. From previous studies of VirB8 protein function, the higher transient transformation efficiency of the HspL overexpression strain may be due to higher VirB8 protein levels and, therefore, may increase T4SS machinery stability and function. Previous studies also demonstrated that sHsps in other organisms may act as membrane-stabilizing factors and may play a role in controlling the integrity of membranes (40). In addition, overexpression of HspL might modify the bacteria membrane property and affect T4SS machinery stability. Hence, overexpression of $\mathrm{HspL}$ may increase A. tumefaciens virulence at early stages, such as T-DNA and effector Vir protein transfer, during A. tumefaciens infection and possibly enhance $A$. tumefaciens virulence when infecting several recalcitrant Arabidopsis ecotypes.

A. tumefaciens-mediated plant transformation has been the most commonly used genetic transformation method during the past few decades. Genes within the T-DNA can be replaced by almost any gene of interest; therefore, A. tumefaciens is an important and valuable tool for plant biology research and genetic engineering. However, this technique cannot efficiently be used for many economically important plant species or elite varieties of particular crop species. Hence, several strategies have been used to enhance $A$. tumefaciens transformation efficiency, including use of the supervirulent A. tumefaciens strain EHA101 that contains the disarmed version of the supervirulent $\mathrm{Ti}$ plasmid pTiBo542 or superbinary vectors that carry additional virB, virG, and virE genes of pTiBo542 $(3,14,20,27,28)$. Our study provides another approach to enhance $A$. tumefaciens-mediated plant transformation efficiency by overexpressing the HspL protein in wildtype A. tumefaciens. Further investigation of this HspL overexpression strain on different recalcitrant crop species may provide useful information for more efficiently generating transgenic crops.

\section{ACKNOWLEDGMENTS}

We thank C. Baron (Department of Biochemistry, Université de Montréal, Canada) for providing the VirB8 antibody, C. Kado (Department of Plant Pathology, University of California, Davis) for providing antibodies for VirB2, and the Hwang and Lai laboratory members for discussion and technical assistance. This research was funded by the National Science Council, Taiwan (NSC 95-2320-B-001-009 to E.-M. Lai and NSC1002311-B-005-002 to H.-H. Hwang).

\section{LITERATURE CITED}

1. Aguilar, J., Zupan, J., Cameron, T. A., and Zambryski, P. C. 2010. Agrobacterium type IV secretion system and its substrates form helical arrays around the circumference of virulence-induced cells. Proc. Natl. Acad. Sci. USA 107:3758-3763.

2. Aly, K. A., and Baron, C. 2007. The VirB5 protein localizes to the T-pilus tips in Agrobacterium tumefaciens. Microbiology 153:3766-3775.

3. Anami, S., Njuguna, E., Coussen, G., Aesaert, S., and Van Lijsebettens, M. 2013. Higher plant transformation: Principles and molecular tools. Int. J. Dev. Biol. 57:483-494.

4. Balsiger, S., Ragaz, C., Baron, C., and Narberhaus, F. 2004. Replicon 
specific regulation of small heat shock genes in Agrobacterium tumefaciens. J. Bacteriol. 186:6824-6829.

5. Baron, C. 2006. VirB8: A conserved type IV secretion system assembly factor and drug target. Biochem. Cell Biol. 84:890-899.

6. Baron, C., Domke, N., Beinhofer, M., and Hapfelmeier, S. 2001. Elevated temperature differentially affects virulence, VirB protein accumulation, and T-pilus formation in different Agrobacterium tumefaciens and Agrobacterium vitis strains. J. Bacteriol. 183:6852-6861.

7. Basha, E., O’Neill, H., and Vierling, E. 2012. Small heat shock proteins and $\alpha$-crystallins: Dynamic proteins with flexible functions. Trends Biochem. Sci. 37:106-117.

8. Bhattacharya, A., Sood, P., and Citovsky, V. 2010. The roles of plant phenolics in defence and communication during Agrobacterium and Rhizobium infection. Mol. Plant Pathol. 11:705-719.

9. Bhatty, M., Laverde Gomez, J. A., and Christie, P. J. 2013. The expanding bacterial type IV secretion lexicon. Res. Microbiol. 164:620-639.

10. Cascales, E., and Christie, P. J. 2004. Definition of a bacterial type IV secretion pathway for a DNA substrate. Science 304:1170-1173.

11. Das, A., and Xie, Y. H. 2000. The Agrobacterium T-DNA transport pore proteins VirB8, VirB9, and VirB10 interact with one another. J. Bacteriol. 182:758-763.

12. Ding, Z., Zhao, Z., Jakubowski, S. J., Krishnamohan, A., Margolin, W., and Christie, P. J. 2002. A novel cytology-based, two-hybrid screen for bacteria applied to protein-protein interaction studies of a type IV secretion system. J. Bacteriol. 184:5572-5582.

13. Eisenbrandt, R., Kalkum, M., Lai, E. M., Lurz, R., Kado, C. I., and Lanka, E. 1999. Conjugative pili of IncP plasmids, and the Ti plasmid T pilus are composed of cyclic subunits. J. Biol. Chem. 274:22548-22555.

14. Frame, B. R., Shou, H., Chikwamba, R. K., Zhang, Z., Xiang, C., Fonger, T. M., Pegg, S. E. K., Li, B., Nettleton, D. S., Pei, D., and Wang, K. 2002. Agrobacterium tumefaciens-mediated transformation of maize embryos using a standard binary vector system. Plant Physiol. 129:13-22.

15. Fullner, K. J., Lara, L. C., and Nester, E. W. 1996. Pilus assembly by Agrobacterium T-DNA transfer genes. Science 273:1107-1109.

16. Garrido, C., Paul, C., Seigneuric, R., and Kampinga, H. H. 2012. The small heat shock proteins family: The long forgotten chaperones. Int. J. Biochem. Cell Biol. 44:1588-1592.

17. Gelvin, S. B. 2010. Plant proteins involved in Agrobacterium-mediated genetic transformation. Annu. Rev. Phytopathol. 48:45-68.

18. Hajdukiewicz, P., Svab, Z., and Maliga, P. 1994. The small versatile pPZP family of Agrobacterium binary vectors for plant transformation. Plant Mol. Biol. 25:989-994.

19. Hiei, Y., Ohta, S., Komari, T., and Kumashiro, T. 1994. Efficient transformation of rice (Oryza sativa L.) mediated by Agrobacterium and sequence analysis of the boundaries of the T-DNA. Plant J. 6:271-282.

20. Hood, E. E., Helmer, G. L., Fraley, R. T., and Chilton, M. D. 1986. The hypervirulence of Agrobacterium tumefaciens A281 is encoded in a region of pTiBo542 outside of T-DNA. J. Bacteriol. 168:1291-1301.

21. Hwang, H. H., and Gelvin, S. B. 2004. Plant proteins that interact with VirB2, the Agrobacterium pilin protein, mediate plant transformation. Plant Cell 16:3148-3167.

22. Hwang, H. H., Wang, M. H., Lee, Y. L., Tsai, Y. L., Li, Y. H., Yang, F. J., Liao, Y. C., Lin, S. K., and Lai, E. M. 2010. Agrobacterium-produced and exogenous cytokinin-modulated Agrobacterium-mediated plant transformation. Mol. Plant Pathol. 11:677-690.

23. Jin, S., Song, Y., Deng, W. Y., Gordon, M. P., and Nester, E. W. 1993. The regulatory VirA protein of Agrobacterium tumefaciens does not function at elevated temperatures. J. Bacteriol. 175:6830-6835.

24. Kado, C. I., and Heskett, M. G. 1970. Selective media for isolation of Agrobacterium, Corynebacterium, Erwinia, Pseudomonas, and Xanthomonas. Phytopathology 60:969-976.

25. Kampinga, H. H., Hageman, J., Vos, M. J., Kubota, H., Tanguay, R. M., Bruford, E. A., Cheetham, M. E., Chen, B., and Hightower, L. E. 2009. Guidelines for the nomenclature of the human heat shock proteins. Cell Stress Chaperones 14:105-111.

26. Kao, J. C., Perry, K. L., and Kado, C. I. 1982. Indoleacetic acid complementation and its relation to host range specifying genes on the $\mathrm{Ti}$ plasmid of Agrobacterium tumefaciens. Mol. Gen. Genet. 188:425-432.

27. Komari, T., Takakura, Y., Ueki, J., Kato, N., Ishida, Y., and Hiei, Y. 2006. Binary vectors and super-binary vectors. Methods Mol. Biol. 343:15-41.

28. Komori, T., Imayama, T., Kato, N., Ishida, Y., Ueki, J., and Komari, T. 2007. Current status of binary vectors and superbinary vectors. Plant Physiol. 145:1155-1160.

29. Koncz, C., and Schell, J. 1986. The promoter of TL-DNA gene 5 controls the tissue-specific expression of chimaeric genes carried by a novel type of Agrobacterium binary vector. Mol. Gen. Genet. 204:383-396.

30. Kumar, R. B., Xie, Y. H., and Das, A. 2000. Subcellular localization of the Agrobacterium tumefaciens T-DNA transport pore proteins: VirB8 is essential for the assembly of the transport pore. Mol. Microbiol. 36:608-617.
31. Lacroix, B., and Citovsky, V. 2013. The roles of bacterial and host plant factors in Agrobacterium-mediated genetic transformation. Int. J. Biochem. Cell Biol. 57:467-481.

32. Lai, E. M., Eisenbrandt, R., Kalkum, M., Lanka, E., and Kado, C. I. 2002. Biogenesis of T pili in Agrobacterium tumefaciens requires precise VirB2 propilin cleavage and cyclization. J. Bacteriol. 184:327-330.

33. Lai, E. M., and Kado, C. I. 1998. Processed VirB2 is the major subunit of the promiscuous pilus of Agrobacterium tumefaciens. J. Bacteriol. 180:2711-2717.

34. Laksanalamai, P., and Robb, F. T. 2004. Small heat shock proteins from extremophiles: A review. Extremophiles 8:1-11.

35. Lee, J. H., Hubel, A., and Schoffl, F. 1995. Derepression of the activity of genetically engineered heat shock factor causes constitutive synthesis of heat shock proteins and increased thermotolerance in transgenic Arabidopsis. Plant J. 8:603-612.

36. Lin, J. S., Ma, L. S., and Lai, E. M. 2013. Systematic dissection of the Agrobacterium type VI secretion system reveals machinery and secreted components for subcomplex formation. PLoS One 8:e67647.

37. Mittler, R., Finka, A., and Goloubinoff, P. 2012. How do plants feel the heat? Trends Biochem. Sci. 37:118-125.

38. Morrow, G., and Tanguay, R. M. 2012. Small heat shock protein expression and functions during development. Int. J. Biochem. Cell Biol. 44:1613-1621.

39. Mysore, K. S., Nam, J., and Gelvin, S. B. 2000. An Arabidopsis histone H2A mutant is deficient in Agrobacterium T-DNA integration. Proc. Natl. Acad. Sci. USA 97:948-953.

40. Nakamoto, H., and Vígh, L. 2007. The small heat shock proteins and their clients. Cell. Mol. Life Sci. 64:294-306

41. Nam, J., Matthysse, A. G., and Gelvin, S. B. 1997. Differences in susceptibility of Arabidopsis ecotypes to crown gall disease may result from a deficiency in T-DNA integration. Plant Cell 9:317-333.

42. Narberhaus, F. 2002. Alpha-crystallin-type heat shock proteins: Socializing minichaperones in the context of a multichaperone network. Microbiol. Mol. Biol. Rev. 66:64-93.

43. Pitzschke, A., and Hirt, H. 2010. New insights into an old story: Agrobacterium-induced tumour formation in plants by plant transformation. EMBO J. 29:1021-1032.

44. Prandl, R., Hinderhofer, K., Eggers-Schumacher, G., and Schoffl, F. 1998. HSF3, a new heat shock factor from Arabidopsis thaliana, derepresses the heat shock response and confers thermotolerance when overexpressed in transgenic plants. Mol. Gen. Genomics 258:269-278.

45. Richter, K., Haslbeck, M., and Buchner, J. 2010. The heat shock response: Life on the verge of death. J. Mol. Cell 40:253-266.

46. Sambrook, J., and Russell, D. 2001. Molecular Cloning: A Laboratory Manual, 3rd ed. Cold Spring Harbor Laboratory, Cold Spring Harbor, NY.

47. Sarkar, N. K., Kim, Y. K., and Grover, A. 2009. Rice sHsp genes: Genomic organization and expression profiling under stress and development. BMC Genomics 10:393.

48. Schmidt-Eisenlohr, H., Domke, N., Angerer, C., Wanner, G., Zambryski, P. C., and Baron, C. 1999. Vir proteins stabilize VirB5 and mediate its association with the T pilus of Agrobacterium tumefaciens. J. Bacteriol. 181:7485-7492.

49. Shirasu, K., and Kado, C. I. 1993. Membrane location of the Ti plasmid VirB proteins involved in the biosynthesis of a pilin-like conjugative structure on Agrobacterium tumefaciens. FEMS Microbiol. Lett. 111:287294.

50. Simon, R., Priefer, U., and Puhler, A. 1983. A broad host range mobilization system for in vivo genetic engineering: Transposon mutagenesis in gram negative bacteria. Biotechnology 1:784-791.

51. Sivanesan, D., and Baron, C. 2011. The dimer interface of Agrobacterium tumefaciens VirB8 is important for type IV secretion system function, stability, and association of VirB2 with the core complex. J. Bacteriol. 193:2097-2106.

52. Soto, A., Allona, I., Collada, C., Guevara, M. A., Casado, R., RodriguezCerezo, E., Aragoncillo, C., and Gomez, L. 1999. Heterologous expression of a plant small heat-shock protein enhances Escherichia coli viability under heat and cold Stress. Plant Physiol. 120:521-528.

53. Sun, W., Van Montagu, M., and Verbruggen, N. 2002. Small heat shock proteins and stress tolerance in plants. Biochim. Biophys. Acta 1577:1-9.

54. Sun, Y., and MacRae, T. H. 2005. Small heat shock proteins: Molecular structure and chaperone function. Cell. Mol. Life Sci. 62:2460-2476.

55. Sundbya, C., Hrndahl, U., Gustavsson, N., Ahrmana, E., and Murphy, D. J. 2005. Conserved methionines in chloroplasts. Biochim. Biophys. Acta 1703:191-202.

56. Tomlinson, A. D., Ramey-Hartung, B., Day, T. W., Merritt, P. M., and Fuqua, C. 2010. Agrobacterium tumefaciens ExoR represses succinoglycan biosynthesis and is required for biofilm formation and motility. Microbiology 156:2670-2681.

57. Tsai, Y. L., Chiang, Y. R., Narberhaus, F., Baron, C., and Lai, E. M. 2010. The small heat shock protein HspL Is a VirB8 chaperone promoting type 
IV secretion-mediated DNA transfer. J. Biol. Chem. 285:19757-19766.

58. Tsai, Y. L., Chiang, Y. R., Wu, C. F., Narberhaus, F., and Lai, E. M. 2012. One out of four: HspL but no other small heat shock protein of Agrobacterium tumefaciens acts as efficient virulence-promoting VirB8 chaperone. PLoS One 7:e49685.

59. Tsai, Y. L., Wang, M. H., Gao, C., Klusener, S., Baron, C., Narberhaus, F., and Lai, E. M. 2009. Small heatshock protein HspL is induced by VirB protein(s) and promotes VirB/D4-mediated DNA transfer in Agrobacterium tumefaciens. Microbiology 155:3270-3280.

60. Waksman, G., and Orlova E. V. 2014. Structural organisation of the type IV secretion systems. Curr. Opin. Microbiol. 17:24-31.

61. Ward, D. V., Draper, O., Zupan, J. R., and Zambryski, P. C. 2002. Peptide linkage mapping of the Agrobacterium tumefaciens vir-encoded type IV secretion system reveals protein subassemblies. Proc. Natl. Acad. Sci. USA 99:11493-11500.

62. Yeh, C. H., Chang, P. C. L., Yeh, K. W., Lin, W. C., Chen, Y. M., and Lin, C. Y. 1997. Expression of a gene encoding a 16.9-kDa heat-shock protein,
Oshsp16.9, in Escherichia coli enhances thermotolerance. Proc. Natl. Acad. Sci. USA 94:10967-10972.

63. Yuan, Q., Carle, A., Gao, C., Sivanesan, D., Aly, K. A., Hoppner, C., Krall, L., Domke, N., and Baron, C. 2005. Identification of the VirB4VirB8-VirB5-VirB2 pilus assembly sequence of type IV secretion systems. J. Biol. Chem. 280:26349-26359.

64. Zechner, E. L., Lang, S., and Schildbach, J. F. 2012. Assembly and mechanisms of bacterial type IV secretion machines. Philos. Trans. R. Soc. B Biol. Sci. 367:1073-1087.

65. Zhu, Y., Nam, J., Humara, J. M., Mysore, K. S., Lee, L. Y., Cao, H., Valentine, L., Li, J., Kaiser, A. D., Kopecky, A. L., Hwang, H. H., Bhattacharjee, S., Rao, P. K., Tzfira, T., Rajagopal, J., Yi, H., Veena, Yadav, B. S., Crane, Y. M., Lin, K., Larcher, Y., Gelvin, M. J., Knue, M., Ramos, C., Zhao, X., Davis, S. J., Kim, S. I., Ranjith-Kumar, C. T., Choi, Y. J., Hallan, V. K., Chattopadhyay, S., Sui, X., Ziemienowicz, A., Matthysse, A. G., Citovsky, V., Hohn, B., and Gelvin, S. B. 2003. Identification of Arabidopsis rat mutants. Plant Physiol. 132:494-505. 